\title{
Cellulolytic and xylanolytic activities of common indoor fungi
}

\author{
Andersen, Birgitte; Poulsen, Rehab; Hansen, Gustav Hammerich
}

Published in:

International Biodeterioration \& Biodegradation

Link to article, DOI:

10.1016/j.ibiod.2015.11.012

Publication date:

2016

Document Version

Peer reviewed version

Link back to DTU Orbit

Citation (APA):

Andersen, B., Poulsen, R., \& Hansen, G. H. (2016). Cellulolytic and xylanolytic activities of common indoor fungi. International Biodeterioration \& Biodegradation, 107, 111-116. https://doi.org/10.1016/j.ibiod.2015.11.012

\section{General rights}

Copyright and moral rights for the publications made accessible in the public portal are retained by the authors and/or other copyright owners and it is a condition of accessing publications that users recognise and abide by the legal requirements associated with these rights.

- Users may download and print one copy of any publication from the public portal for the purpose of private study or research.

- You may not further distribute the material or use it for any profit-making activity or commercial gain

- You may freely distribute the URL identifying the publication in the public portal

If you believe that this document breaches copyright please contact us providing details, and we will remove access to the work immediately and investigate your claim 
1 To: International Biodeterioration \& Biodegradation

2

3

4

5

6 7

8

9

\title{
Cellulolytic and xylanolytic activities of common indoor fungi
}

\author{
Birgitte Andersen*, Rehab Poulsen and Gustav H. Hansen
}

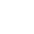

8

Section for Eukaryotic Biotechnology, DTU Systems Biology, Søltofts Plads, Technical University of Denmark, DK-2800 Kgs. Lyngby, Denmark

*Corresponding author: E-mail: ba@bio.dtu.dk (Birgitte Andersen)

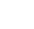

(4)

Keywords: AZCL enzyme assay, endo-enzymes, wheat bran/sphagnum peat medium

\section{ABSTRACT}

Mouldy building materials, such as chip wood and gypsum, should be a good source for fungal strains with high production of lignocellulolytic enzymes. Screening of 21 common indoor fungal strains showed, contrary to the expected, that the Chaetomium and Stachybotrys strains had little or no cellulolytic and xylanolytic activities using AZCL-assays. On the other hand, both Cladosporium sphaerospermum and Penicillium chrysogenum showed the highest cellulase, $\beta$-glucosidase, mannase, $\beta$-galactanase and arabinanase activities and would be good candidates for over-producers of enzymes needed to supplement or boost the bioconversion of lignocellulose-rich biomass. 


\section{Introduction}

Filamentous fungi are among the most efficient degraders of plant biomass, whether it is undesired, as in the deterioration of Army Cotton Canvas, or by design, as in the bioconversion of organic waste material. They are, therefore, the main source of commercial lignocellulase production (Glass et al., 2013) and high yielding fungal strains are always in demand in the biotech industry (Pedersen et al., 2009; Hansen et al., 2015). The most commonly used organism for commercial enzyme production is Trichoderma reesei (Glass et al., 2013), but it has its limitations. Trichoderma reesei produces a high amount of exo-cellulases, but is a poorer producer of e.g. $\beta$-glucosidase (Okeke, 2014).

Research and screening of filamentous fungi for new high-yielding strains have shown that the original habitat of a strain is important in order to get as specific an enzyme profile as possible. Most of the commercial enzyme producers originate from habitats and substrates rich in lignocellulose, such as compost or agricultural soil (Hansen et al., 2015). Pedersen et al. (2008) showed that Ulocladium strains originating from cereal grain (starch) had the highest production of amylase compared to strains from the indoor environment (lignocellulose), which in return had the highest production of arabinanase.

Incidences of fungal deterioration of indoor environments are increasing and can now be seen in most of the western world (WHO, 2010). It is most obvious on lignocellulose rich materials, such as chip wood or plywood, where the fungal growth can be substantial. It has been shown that there are particular fungal associations between 1) Cladosporium sphaerospermum and plywood 2) Stachybotrys chartarum and gypsum board and 3) Ulocladium alternariae and wallpaper (Andersen et al., 2011). Mouldy building materials should therefore be a good source for discovery of fungal strains that either produce novel enzyme profiles or over-produce known desirable enzymes. 
The purpose with this study was to screen and compare the ten most common fungal species from waterdamaged buildings for their production of lignocellulases using T. reesei RUT C30 as a reference strain.

\section{Materials and Methods}

2.1. Fungal strains, media, growth conditions and enzyme extraction

Twenty-one common indoor strains and one reference strain were used in the study. The identity, source and geographic origin of all fungi are listed in Table 1. All fungal strains are held at the IBT culture collection at Department for Systems Biology, DTU, Denmark. To generate inoculum and check the identity, each strain was inoculated on Campbell's V8 juice agar (V8, Samson et al., 2010) and incubated for 7 days at 25

${ }^{\circ} \mathrm{C}$. For enzyme production a semi-solid wheat bran/sphagnum peat (WB/SP) medium was made containing (per kg): $256.25 \mathrm{~g}$ wheat bran (Finax, Denmark), $153.75 \mathrm{~g}$ sphagnum peat (Mosebrug, Denmark) and $590 \mathrm{~g}$ water. $40.0 \mathrm{~g}$ of WB/SP medium was placed in each $250 \mathrm{ml}$ shake flask and autoclaved. Each fungal strain was inoculated by cutting 3 agar plugs (10 $\mathrm{mm}$ in diameter) with spores and mycelium from the V8 plate and transferring these to the shake flask with the WB/SP medium. The shake flasks were incubated at $25^{\circ} \mathrm{C}$ and shaken twice a day manually for one week. The experiment was performed in triplicates (66 shake flasks in total).

\section{6}

Each shake flask was added $50 \mathrm{ml}$ double distilled autoclaved water and shaken at $175 \mathrm{rpm}$ overnight at 4

${ }^{\circ} \mathrm{C}$. Each extract was filtered through Miracloth into a $50 \mathrm{ml}$ falcon tube and centrifuged at $10,000 \mathrm{~g}$ at $5{ }^{\circ} \mathrm{C}$ for $15 \mathrm{~min}$. The supernatant (enzyme extract) was transferred to a clean $50 \mathrm{ml}$ falcon tube and stored at $4^{\circ} \mathrm{C}$ prior to screening.

\subsection{AZCL assay preparation and screening}


Six different Azurine cross-linked (AZCL) substrates were used for screening: arabinan, arabinoxylan (wheat and birchwood), HE-cellulose, galactan and $\beta$-galactomannan (Megazyme, Bray, Ireland). For each AZCL assay plates were made containing (per $500 \mathrm{ml}$ ): $144 \mathrm{ml}$ stock solution, $356 \mathrm{ml}$ double distilled water, $7.5 \mathrm{~g}$ agarose (Litex, HSB 200 Protein grade) and $0.5 \mathrm{~g}$ AZCL substrate. The stock solution consisted of phosphoric acid (0.08 M) (Merck, Ortho-Phosphorsaure, $85 \%)$, glacial acetic acid (0.08 M) (Merck, $100 \%$ ) and boric acid $(0.08 \mathrm{M})$ (Merck) in double distilled water. To prepare the different AZCL assay plates, $200 \mathrm{ml}$ double distilled water was added to the $144 \mathrm{ml}$ stock solution. The $\mathrm{pH}$ was adjusted to 6 and double distilled water was added again to give a total volume of $500 \mathrm{ml}$. Agarose was added and the solution was autoclaved at $120{ }^{\circ} \mathrm{C}$. The AZCL substrate was pre-soaked in $96 \%$ ethanol for $10 \mathrm{~min}$ before use. When the agarose solution had cooled to approximately $65^{\circ} \mathrm{C}$, the $\mathrm{AZCL}$ substrate suspension was added while stirring. The agarose solution was poured into Petri dishes (90 $\mathrm{mm}$ in diam.) and when solidified, 8 wells (5 $\mathrm{mm}$ in diam.) were cut in the plates and stored at $4{ }^{\circ} \mathrm{C}$.

For screening $35 \mu$ l of enzyme extract was added to each well of the six different AZCL assay plates. The plates were incubated for $24 \mathrm{~h}$ at $30{ }^{\circ} \mathrm{C}$. The activity of each enzyme was measured as the radius of the zone of released azurine dye (the blue halo) around each application well. The radius was recorded and converted to area $\left(\mathrm{mm}^{2}\right)$.

\section{3. $\beta$-glucosidase assay and screening}

Screening for $\beta$-glucosidase activity was done using para-nitrophenyl- $\beta$-D-glucopyranoside (pNPG) 5 mM (Sigma Aldrich) as substrate in $50 \mathrm{mM}$ sodium citrate $(\mathrm{pH} \mathrm{4.8).} \mathrm{The} \mathrm{screening} \mathrm{was} \mathrm{carried} \mathrm{out} \mathrm{in} \mathrm{a}$ microtiter-plate format according to (Sørensen et al., 2011). A $10 \mu$ l volume of enzyme extract was added to $100 \mu \mathrm{l}$ substrate in $1.5 \mathrm{ml}$ Eppendorf tubes and incubated in a Thermomixer ${ }^{\circledast}$ comfort (Eppendorf) at 50 ${ }^{\circ} \mathrm{C}$ for $15 \mathrm{~min}$. At the end of the reaction $60 \mu \mathrm{l}$ of the reaction volume was transferred to a microtiter plate already containing $100 \mu \mathrm{l} 1 \mathrm{M} \mathrm{Na}_{2} \mathrm{CO}_{3}$ for termination of the reaction. Absorbance at $400 \mathrm{~nm}$ was measured 
in a plate reader (BioTek, EL800). Para-nitrophenol was used for preparation of a standard curve. One unit (U) of enzyme activity was defined as the volume of enzyme needed to hydrolyze $1 \mu \mathrm{mol}$ of pNPG in $1 \mathrm{~min}$. Background subtraction was prepared for each sample with $100 \mu \mathrm{l}$ substrate at reaction temperature. Hereafter, $100 \mu \mathrm{l}$ stop reagent was added to the Eppendorf tube then $10 \mu \mathrm{l}$ enzyme for reaction time 15 min. $160 \mu \mathrm{l}$ of the reaction mixture was then transferred to the microtiter plate and the absorbance was measured at $400 \mathrm{~nm}$.

\section{Results}

The AZCL enzyme screenings of the 21 indoor strains were made from crude enzyme extracts from 7 dayold wheat bran/sphagnum peat (WB/SP) medium in solid state fermentations. The analyses showed that both Chaetomium elatum and C. globosum had low or no cellulase, mannase or galactanase activities (Fig. 1) with the exception of $C$. globosum (IBT 7029) that had an average mannase activity, compared to the highest activities (Fig. 1b). None of the strains of Stachybotrys chartarum or S. chlorohalonata showed any cellulase, mannase or $\beta$-galactanase activity (Fig. 1). Penicillium chrysogenum showed the highest cellulase and mannase activities (Fig. 1a and b), while Cladosporium sphaerospermum showed the highest galactanase activity (Fig. 1C). Trichoderma, including the reference strain (T. reesei RUT C30), had in general good cellulase and mannase activities, but very low galactanase activity (Fig. 1).

The $\beta$-glucosidase screening again showed that all the Chaetomium and Stachybotrys strains had a very low activity $(0.008-0.154 \mathrm{U} / \mathrm{ml})$ compared to the reference strain (T. reesei RUT C30) that had an activity of $0.513 \mathrm{U} / \mathrm{ml}$ (Fig. 2a). Compared to the high activities $(7.823-7.653 \mathrm{U} / \mathrm{ml}$ ) shown by $P$. chrysogenum and $C$. sphaerospermum, both T. harzianum and T. reesei (RUT C30) showed low activities (Fig. 2b). 
The screening for xylanase production was done on xylan from both wheat and birch and gave similar results (Fig 3a and b). It showed all ten Chaetomium and Stachybotrys strains as the low producers, while Aspergillus versicolor and T. harzianum were the high producer for both types of xylanases (Fig. 3a and b).

The arabinanase screening, however, showed that neither T. harzianum nor $A$. versicolor had any activity, while P. chrysogenum had the highest (Fig. 3c). Some of the Chaetomium and Stachybotrys strains had average activities (e.g. C. globosum (IBT 7029) and S. chlorohalonata (IBT 40285)), while others showed no arabinanase activity after growth on the WB/SP medium.

A Principal Component Analysis in Figure 4 of all the enzyme screenings shows that Chaetomium and Stachybotrys (to the left) had similar enzyme profiles, with a general low activity of all tested enzymes. Aspergillus and Trichoderma (at the bottom) also had similar profiles, both showing high xylanase activities, average cellulase, $\beta$-glucosidase and mannase activities and low or no $\beta$-galactanase and arabinanase activities. Penicillium, Cladosporium and to some extent Ulocladium (at the top) were similar in having average to high activities of all enzymes tested.

Three strains, C. globosum (IBT 7029), U. alternariae (IBT 9058) and T. harzianum (41332) fell outside their respective groups. Chaetomium globosum (IBT 7029) had, overall, a higher activity than the other Chaetomium strains, while U. alternariae (IBT 9058) and T. harzianum (41332) had a lower activity compared to their sibling strains.

\section{Discussion}

Wheat bran/sphagnum peat (WB/SP) medium was used since it has been shown to be superior in inducing a broad variety of enzymes (Kolasa M. et al., 2014; Meijer M. et al., 2011). WB was also the medium of choice in the study of Pedersen et al., (2009), where 50 Ulocladium strains were screened for enzyme 
activity using the AZCL substrates. An attempt to grow the indoor fungi on a similarly composed medium with crushed chipboard/wallpaper instead of wheat bran/sphagnum peat resulted in no growth, probably because the fungi needed a higher water activity to grow on this medium than WB/SP.

The study of Pedersen et al. (2009) also showed that there was variation between strains of the same species. This was also seen in this study, for example, with the three Penicillium chrysogenum strains that showed similar enzyme profiles in most assays, except for mannose, where $P$. chrysogenum (IBT 30128) had no activity, while the other two strains had the highest activity.

The cellulolytic and xylanolytic activities of Chaetomium and Stachybotrys have been reported since the 1920s, where the fungi destroyed military equipment and other outdoor cotton fabrics (Greathouse and Ames, 1945; Domsch et al., 2007). The results in this study show, contrary to the expected, that the Chaetomium and Stachybotrys strains originating from water-damaged building materials showed little or no cellulolytic and xylanolytic activities using AZCL-assays. Even C. globosum (IBT $7029=$ CBS $148.51=$ USDA 1042.4), which has been used for material testing (Reese et al., 1950), showed only average activities in the AZCL assays. The fact that these fungi still are able to grow and destroy cellulose-rich building materials, suggests that they have only exo-enzymes and/or membrane bound endo-enzymes, since the AZCL assays screen for extracellular endo-enzymes (Vidal-Melgosa et al., 2015). Also the low $\beta$-glucosidase activity suggests that these enzymes are membrane bound or intracellular. Another reason could be that Chaetomium and Stachybotrys can utilize other carbon sources than cellulose in the building materials. Similar results were seen for Trichoderma. The low $\beta$-glucosidase activity for $T$. reesei in this study is in accordance with other studies (Okeke, 2014) and it has been suggested that this enzyme is membrane bound or intracellular (Kubicek et al., 2009). 
171 The other indoor fungi have larger varieties and higher activities of endo-enzymes compared to 172 Chaetomium and Stachybotrys, which might explain their higher frequency on and lesser specificity for 173 water-damaged building materials (Andersen et al., 2011). P. chrysogenum showed the highest activities for 174 most of the screened enzymes, which might explain its occurrence on most damp indoor surfaces. $C$. sphaerospermum showed a similar result to that of $P$. chrysogenum, however, this fungus is more specialized and also associated with plaster and grouts in bathrooms, due to its ability also to tolerate high fluctuations in humidity (McGinnis, 2007).

The hypothesis of this study, that mouldy buildings constitute a good source for high cellulase and xylanase producers, was partly proven, but not with the fungal species expected. However, both C. sphaerospermum and $P$. chrysogenum would be good candidates for over-producers of enzymes needed to supplement or boost e.g. T. reesei in bioconversion of e.g. garden/park waste or other lignocellulosic biomass into bio-fuel.

\section{Acknowledgements}

The authors would like to thank the VILLUM foundation (Control and Prevention of Fungal Growth in Buildings) and the Danish Council for Strategic Research (MycoFuelChem, Grant No. 11-116803) for the financial support.

\section{References}

Andersen B, Frisvad JC, Søndergaard I, Rasmussen IS \& Larsen LS. (2011). Associations between fungal species and water damaged building materials. Applied and Environmental Microbiology. 77: 4180-8.

Domsch KH, Gams W, Anderson T-H. (2007). Compendium of Soil Fungi. 2. Ed. IHW-Verlag, Eching bei München. pp. 1-672.

Glass NL, Schmoll M, Cate JHD, Coradetti S. (2013). Plant Cell Wall Deconstruction by Ascomycete Fungi. Annual Review of Microbiology 67: 477-98. 
Greathouse GA, Ames LM. (1945). Fabric deterioration by thirteen described and three new species of Chaetomium. Mycologia 37: 138-55.

Hansen GH, Lübeck M, Frisvad JF, Andersen B. (2015). Production of cellulolytic enzymes from ascomycetes: Comparison of solid state and submerged fermentation. Process Biotechnology 50: 1327-41.

Kolasa M, Ahring BK, Lübeck PS, Lübeck M. (2014). Co-cultivation of Trichoderma reesei RutC30 with three black Aspergillus strains facilitates efficient hydrolysis of pretreated wheat straw and shows promises for on-site enzyme production. Bioresource Technology 169: 143-48.

Kubicek CP, Mikus M, Schuster A, Schmoll M, Seiboth B. (2009). Metabolic engineering strategies for the improvement of cellulase production by Hypocrea jecorina. Biotechnololy for Biofuels 2: 1-14.

McGinnis MR. (2007). Indoor mould development and dispersal. Medical Mycology 45: 1-9.

Meijer M, Houbraken JAMP, Dalhuijsen S, Samson RA, de Vries RP. (2011). Growth and hydrolase profiles can be used as characteristics to distinguish Aspergillus niger and other black aspergilli. Studies in Mycology 69: 19-30.

Okeke B. (2014). Cellulolytic and xylanolytic potential of high $\beta$-glucosidase-producing Trichoderma from decaying biomass. Applied Biochemistry and Biotechnology 174: 1581-98.

Pedersen M, Hollensted M, Lange L \& Andersen B. (2009). Screening for cellulose and hemicellulose degrading enzymes from the fungal genus Ulocladium. International Biodeterioration \& Biodegradation 63: 484-9.

Reese ET, Levinson HS, Downing M, White WL. (1950). Quartermaster culture collection. Farlowia 4: 45-86.

Sørensen A, Lübeck PS, Lübeck M, Teller PJ, Ahring BK. (2011). $\beta$-Glucosidases from a new Aspergillus species can substitute commercial $\beta$-glucosidases for saccharification of lignocellulosic biomass. Canadian Journal of Microbiology 650: 638-50.

Samson RA, Houbraken J, Thrane U, Frisvad JC \& Andersen B. (2010). Food and Indoor Fungi. CBS-KNAWFungal Biodiversity Centre, Utrecht, the Netherlands. pp. 1-398. 
221 Vidal-Melgosa S, Pedersen HL, Schückel J, Arnal G, Dumon C, Amby DB, Monrad RN, Westereng B, Willats WGT (2015). A new versatile microarray-based method for high-throughput screening of carbohydrate-active enzymes. J Biol Chem 290: 9020-36.

224 
225 Figure legends

227 Fig.1. Comparisons of enzyme activity for all 22 fungal strains for A: AZCL-HE-cellulose, B: AZCL- $\beta$ 228 galactomannan and C: AZCL-galactan.

229

230 Fig.2. Comparisons of enzyme activity for all 22 fungal strains for $\beta$-D-glucopyranoside. A: Chaetomium and 231 Stachybotrys strains compared with T. reesei (gray). B: T. reesei (gray) compared with Trichoderma, 232 Ulocladium, Cladosporium, Aspergillus and Penicillium strains.

234 Fig.3. Comparisons of enzyme activity for all 22 fungal strains for A: AZCL-arabinoxylan (wheat), B: AZCL235 arabinoxylan (birchwood) and C: AZCL-arabinan.

Fig. 4. Principal Component Analysis of all 7 enzyme activities and all 22 fungal strains. Arbitrary scales. 


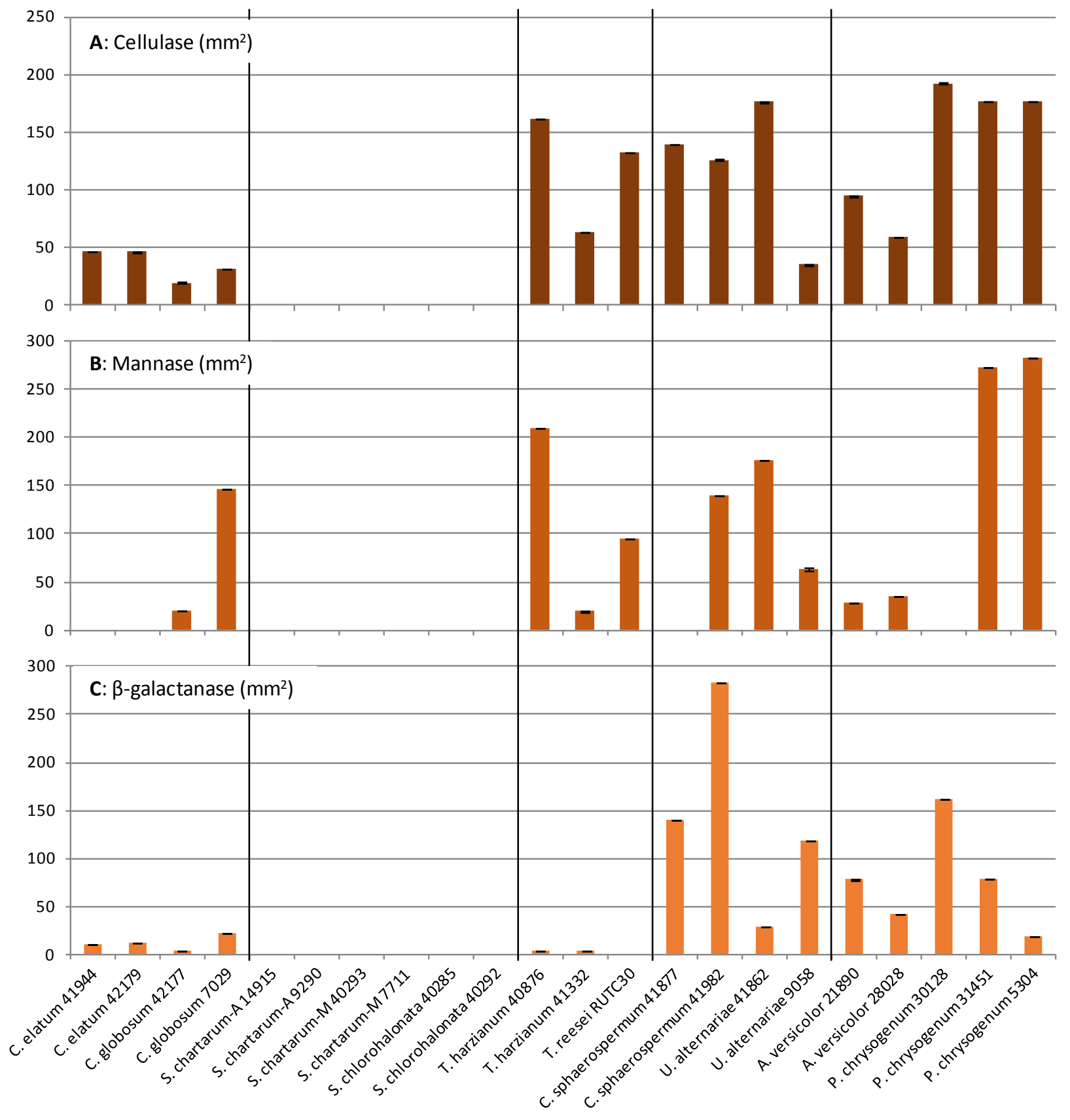

Figure 1 


\section{$\beta$-glucosidase (U/ml)}

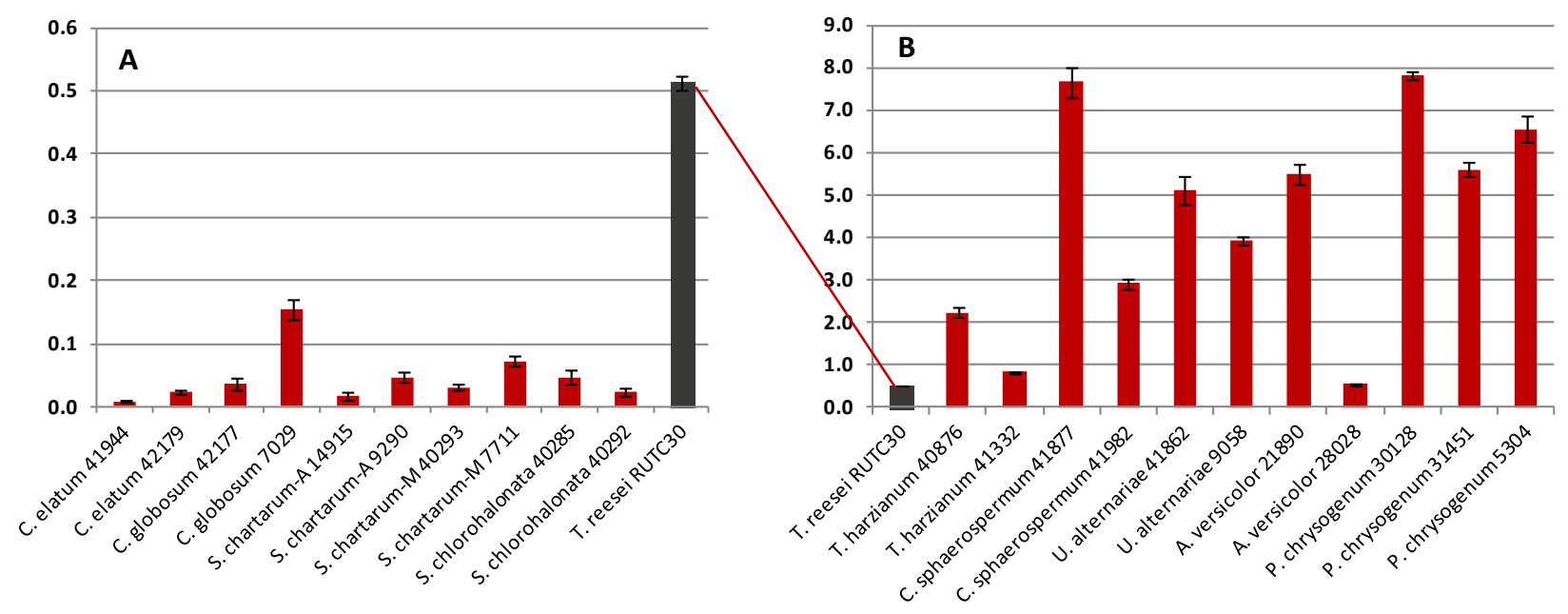

Figure 2 


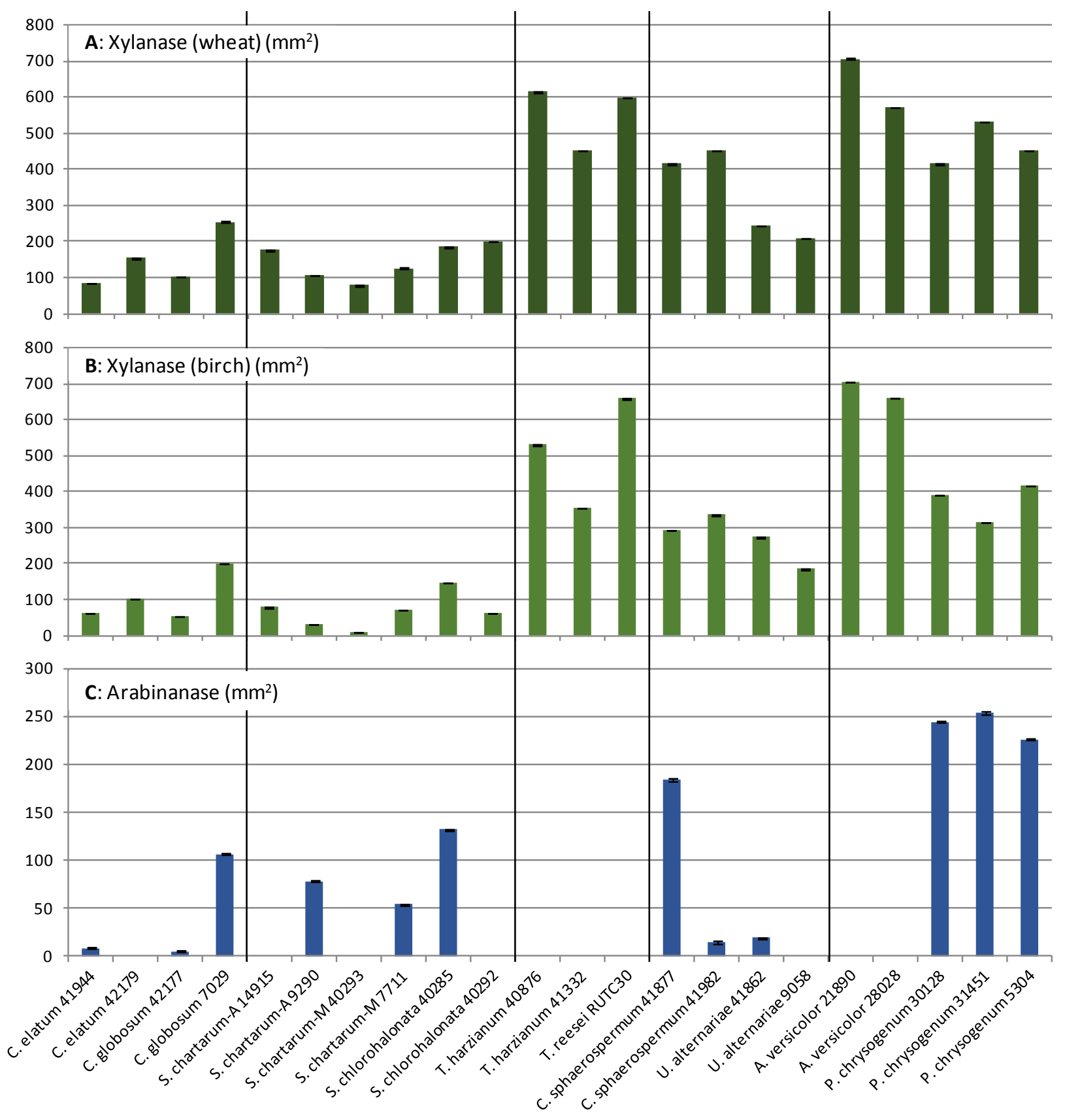

Figure 3 


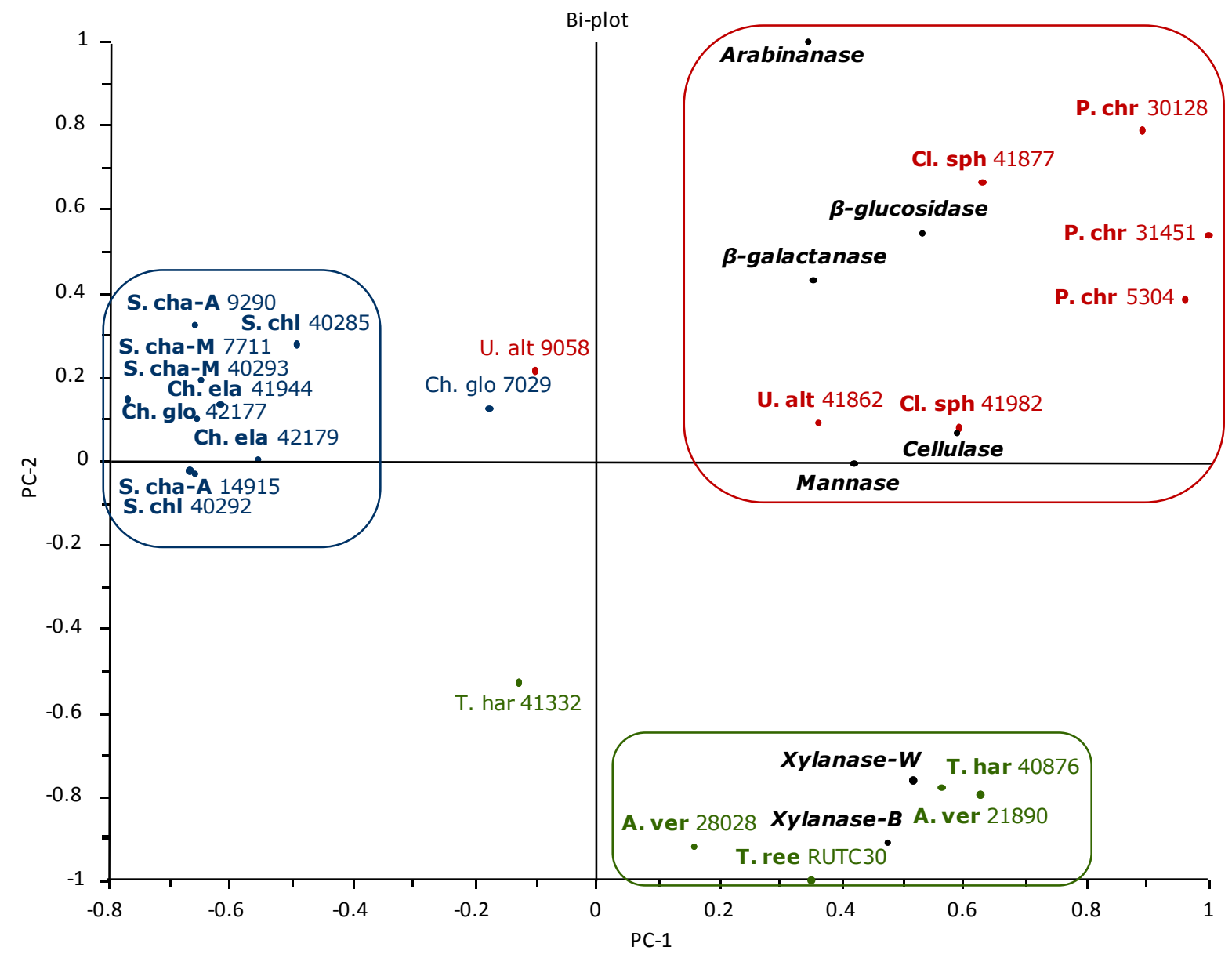

Figure 4 
Table 1. Fungal strains used in this study with identification numbers and origin.

\begin{tabular}{|c|c|c|c|c|}
\hline Genus & Species & IBT no. & Other no. & Origin \\
\hline Aspergillus & versicolor & 21890 & KD 252-2 & Indoor, USA \\
\hline Aspergillus & versicolor & 28028 & NRRL 3499, SRRC 108 &,$- N L$ \\
\hline Chaetomium & elatum & 41944 & BA Home A & Dust on curtain rail, DK \\
\hline Chaetomium & elatum & 42179 & BA Sample 3009 & Cardboard page from photo album, DK \\
\hline Chaetomium & globosum & 7029 & CBS 148.51, USDA 1042.4 & Stored cotton, USA \\
\hline Chaetomium & globosum & 42177 & Krydsfiner X-a & Plywood, DK \\
\hline Cladosporium & sphaerospermum & 41877 & BAV-KD-C1 & Indoor air sample, DK \\
\hline Cladosporium & sphaerospermum & 41982 & B221/914c & Pipe insulation, DK \\
\hline Penicillium & chrysogenum & 5304 & LH 107 & Indoor air sample, DK \\
\hline Penicillium & chrysogenum & 30128 & DTO 78-E5 & Indoor air sample, DK \\
\hline Penicillium & chrysogenum & 31451 & GR11BA 10b-1-1b & Dust from vacuum cleaner, GL \\
\hline Stachybotrys & chartarum (A) & 9290 & $x X$ & Plaster wall, DK \\
\hline Stachybotrys & chartarum (A) & 14915 & ALK 57 & Gypsum board, DK \\
\hline Stachybotrys & chartarum (M) & 7711 & Dyrup-J & Wood, DK \\
\hline Stachybotrys & chartarum (M) & 40293 & 201 & Indoor, USA \\
\hline Stachybotrys & chlorohalonata & 40285 & 204 & Indoor, USA \\
\hline Stachybotrys & chlorohalonata & 40292 & 103 & Indoor, USA \\
\hline Trichoderma & harzianum & 40876 & TMW 4.1880 &,-- \\
\hline Trichoderma & harzianum & 41332 & 16534-a & Indoor air sample, DK \\
\hline Trichoderma & reesei & - & RUT C30 &,-- \\
\hline Ulocladium & alternariae & 9058 & ALK 124 & Indoor air sample, DK \\
\hline Ulocladium & alternariae & 41862 & BA 1886 & Wallpaper, DK \\
\hline
\end{tabular}

